\section{Truth is the daughter of time}

SIR - John Godfrey (Nature 373, 100; $1995)$ attempts to reason with the Pope about human ontogeny. Reason does work with the Roman Catholic Church, but the timescale is the problem. It took 400 years for the Church to admit the truth about Galileo. How long will it take it to admit it is wrong about human reproduction?

My wife and I recently visited Mother Teresa's orphanage in the ghastly slums of Calcutta, and met children who were a small and lucky fraction of the unwanted flotsam of that city of dreadful night. That evening we saw a BBC report about the Pope's fulminations in Manila on the evils of birth control and family planning. The contrast was wrenching.

What is happening in Calcutta would seem at first sight to be irrelevant to the Church's attitude. The parents of these children are (supposing that they have any time for religion) Hindus or Muslims or Jains or whatever. Yet imagine that 30 years ago Pope John XXIII had lived long enough to change the Church's teaching on birth control. Who can doubt that this decision would have resounded through the rest of the religions of the planet, and through the halls of governments everywhere?

The fear is that when, decades or centuries from now, some future Pope changes his mind, this belated decision will be as irrelevant as the Church's "vindication" of Galileo. The difference is that this decision matters. Every year that it is delayed makes it clearer that the Church's current attitude is a crime against humanity. History will judge it so.

\section{Christopher Wills}

Department of Biology 0116 ,

University of California, San Diego,

La Jolla, California 92093, USA

SIR - It is unfortunate that Godfrey missed seeing the forest because of attention paid to the trees. It is also unfortunate that he should berate the Pope for discussing a "moment" when an individual human life begins as being contrary to modern biological knowledge. The establishment of totipotency following fertilization is a well-established fact that is fully consistent with the Pope's criticized discourse. Why quibble over whether the time elapsed is appropriately referred to as an instant or a moment?

The Pope proclaims that every human is precious, a pearl of great price. Yet modern biological knowledge cannot justify ascribing dignity to any human. Science is incapable of preventing a total loss of any sense of human dignity in contemporary culture. A society that rejects equal dignity for all humans is the definition of tyranny. This is a concern shared by people of many faiths, including the Pope. Those who look to science to provide a reason for human dignity will be eternally disappointed. Let us not seek out those humans whom we can feel justified in denying their rights, rather, let us cherish each person.

\section{Warren V. Johnson}

University of Wisconsin-Green Bay,

2420 Nicolet Drive,

Green Bay,

Wisconsin 54311-7001, USA

SIR - I wonder what my students would think if, at the start of my lectures on the cellular aspects of developmental biology, I brainwashed them with Godfrey's slogan that "there is no moment when human life starts". Developmental biology emphasizes the starting point of every new organism. We know well the cellular traits, molecular composition, regions, potentialities and even fate maps of the first cell, the zygote, of flies, sea urchins, nematodes and frogs. Why should human biology be completely different?

Godfrey does not offer any evidence to discredit the long-standing and 'common sense biology' view supporting fertilization as the standard origin for the human individual. It is not "obsolete biology" but a mere description of facts. Even recognizing the complexities of fertilization, its duration included, simple observation shows us that, as with any other animal species, fertilization is the moment when an individual human organism starts its development. The widely used concept of developmental age relies in being able to identify a beginning. If the conclusion of the fertilization process marks the start of every new specimen of Drosophila, Caenorhabditis, Xenopus, Gallus or Mus, the end of fertilization should also be considered the origin of a new human being.

It is not John Paul II who is trying to impose a non-scientifically based description of human first developmental stages. If anybody is trying to force the scientific facts, it is Godfrey. Personally, I cannot offer my students the farce of human embryos without beginning. I prefer telling them that we are having a hard time dealing with the early human embryo: that besides those who respect him/her as a human being, there are others who, in order to justify the deliberate loss or destruction of human embryos, prefer to hold them as not yet clearly defined entities. The pretence of indeterminate origin is simply an element of this scheme. Luls M. Montuenga

Department of Histology and Pathology, University of Navarra,

Pamplona,

Spain

\section{Race plus IQ does not equal science}

SIR - Steve Blinkhorn's recent review (Nature 372, 417-419; 1994) of Herrnstein and Murray's The Bell Curve (and two related books) misses the point. Considered as scientific inquiry, the basic question posed by the authors - is a social "underclass", which performs poorly on IQ tests, doomed to this deficiency by the genes of its members rather than by remediable epigenetic factors? - is unanswerable. The reason for this conclusion is that the list of epigenetic influences that might give rise to the differential behaviour of any large and heterogeneous group of human beings is, for all practical purposes, limitless.

A problem in biology that underlines this point is cell determination. Developing cells are said to be 'determined' when varying the circumstances in which they exist fails to influence what they become. Much pointless argument has been expended over the years because of the erroneous assumption that if a cell's properties are demonstrably stable under some set of testable conditions, its fate is sealed for all conditions. But there are of course always other circumstances that, had they been tested, might have altered a cell's fate. Although the question of cell determination is in principle amenable to analysis, most biologists have avoided it, recognizing the wisdom of Peter Medawar's dictum that success in science depends on studying problems that can actually be solved (The Art of the Soluble, Methuen, 1967).

The role of genes in the determination of IQ (save in the case of monozygotic twins) is doomed to a similar scientific limbo, and should likewise be dropped as a serious issue. Whereas intelligence is in part heritable (as all and sundry admit), it is simply impossible to determine that any group owes a small difference in performance to 'genetic factors'. There will always be other untested (or untestable) epigenetic influences that might explain the discrepancy, as must be especially obvious in the case of 'race' (whatever that means) and IQ. Were the thesis of The Bell Curve not so pernicious, it would be sufficient to let it die a natural death. However, the unfortunate consequences of having so many people, including scientists, take seriously the highly implausible idea of genetically determined racial inferiority is by now obvious. A problem that cannot be solved is not the stuff of science, but of polemics.

\section{Dale Purves}

Department of Neurobiology,

Duke University Medical Center,

Box 3209 ,

Durham, North Carolina 27710, USA 